\title{
Banki finanszírozási kockázatok monitoringja a pénzügyi vállalkozásokra vonatkozóan*
}

\author{
Inzelt György - Szentes-Markhot Zsuzsa - Budai Gábor
}

\begin{abstract}
A 2008-ban kezdődő válságidőszak mind hazai, mind nemzetközi szinten rámutatott arra, hogy a bankokhoz képest kevésbé szigorú prudenciális szabályozási keretben müködő pénzügyi vállalkozások bizonyos esetekben jelentős mértékü hitelkockázatot halmoztak fel, amelyen a refinanszírozó hitelintézetek komoly veszteségeket szenvedtek el. Tanulmányunk a hazánkban müködő pénzügyi vállalkozások bankok általi finanszírozási kockázatainak egy egyszerü, könnyen értelmezhető és cégadatbázisok mérleg-és eredménykimutatás-adatai alapján reprodukálható, viszont stabil teljesítményü, ebböl következően adott esetben széles körben hasznositható, szoros, automatizált nyomon követését lehetővé tevő, jelzölámpa jelleggel müködtethető monitoring eszközt mutat be, mellyel akár középtávon, akár 2 évre elöre mutatóan lehetséges relativ kockázatosságot rendelni a pénzügyi vállalkozásokhoz. Következtetésként megállapítható, hogy fentiek alapján a 2008-ban kezdődő nagy gazdasági világválság elött lehetséges lett volna azonosítani a kockázatos pénzügyi vállalkozásokat, és a banki oldalról adott esetben lezárni vagy hamarabb leépíteni a kockázatos pénzügyi vállalkozásokkal szemben fennálló kitettséget. A publikálás időpontjában tudomásunk szerint ez a fajta kockázatmérési módszertan a hazai szakirodalomban a pénzügyi vállalkozások finanszírozási kockázataira vonatkozóan elözmények nélküli.
\end{abstract}

Journal of Economic Literature (JEL) kódok: G23, C53

Kulcsszavak: nem-banki pénzintézetek, előrejelzés

\section{A magyar pénzügyi vállalkozások jellemzői és felügyelete}

\subsection{A hazai szabályozás és felügyelet}

Jelen tanulmányban a hitelintézetekről és a pénzügyi vállalkozásokról szóló 2013. évi CCXXXVII. törvény (Hpt.) 9. § (1) bekezdése szerinti pénzügyi vállalkozások közül a nem bankcsoporti tulajdonban lévő pénzügyi vállalkozásokat vizsgáljuk.

\footnotetext{
* A jelen kiadványban megjelenő írások a szerzők nézeteit tartalmazzák, ami nem feltétlenül egyezik a Magyar Nemzeti Bank hivatalos álláspontjával.

Inzelt György, a Magyar Nemzeti Bank osztályvezetője, a módszer kidolgozója a tanulmány véglegesítése elött elhunyt.

Szentes-Markhot Zsuzsa a Magyar Nemzeti Bank osztályvezetője. E-mail: markhotzs@mnb.hu

Budai Gábor a Magyar Nemzeti Bank vezető felügyelője. E-mail: budaig@mnb.hu

A magyar nyelvű kézirat első változata 2018. március 29-én érkezett szerkesztőségünkbe.
}

DOI: http://doi.org/10.25201/HSZ.17.4.112139 
A pénzügyi vállalkozások a Hpt. alapján alapvetően a hitelintézetekhez hasonló tevékenységeket végezhetnek - mindkét intézménytípus pénzügyi intézménynek minősül (7. § (1)), és a Hpt. szerint pénzügyi szolgáltatási tevékenységet üzletszerűen kizárólag pénzügyi intézmény végezhet (7. § (2)) - így szabályozásuk is sok szempontból hasonló. A legfontosabb különbség ugyanakkor a két intézménytípus között, hogy a pénzügyi vállalkozások nem gyŭjthetnek betétet, illetve nem nyújthatnak pénzforgalmi szolgáltatást, így az esetlegesen elszenvedett veszteségek elsősorban az őket finanszírozó hitelintézeteken keresztül jelenthetnek az ügyfelek számára is kockázatot. Ebből kifolyólag egy pénzügyi vállalkozás esetleges felszámolása a pénzügyi szolgáltatást igénybe vevő (lakossági, vállalati) ügyfelek szempontjából jóval kisebb negatív hatással jár, mint egy bank esetén. Ezzel összhangban a pénzügyi vállalkozások a hitelintézetekhez képest jóval kisebb induló tőkével (50 millió forinttal) alapíthatók, továbbá az európai uniós tőkemegfelelési rendeletben $\left(\mathrm{CRR}^{1}\right)$ meghatározott tőkekövetelmények sem vonatkoznak rájuk. Utóbbiak tekintetében kivételt képeznek a hitelintézeti tulajdonú, és ennélfogva konszolidációs körbe tartozó pénzügyi vállalkozások.

A 2008-ban kezdődő válság a makroprudenciális szabályozás kiemelt jelentősége mellett többek között arra is rámutatott, hogy a mikroprudenciális szabályozás némely ponton megkerülhető. Az egyik, jelen tanulmány szempontjából releváns kapcsolódó kockázat a pénzügyi vállalkozások refinanszírozása, hiszen ezen a módon a refinanszírozó hitelintézetek - látszólag - nem vállalták fel az esetlegesen saját hitelezési politikájuk által már nem finanszírozható ügyfelek kockázatát. A válság évei során ugyanakkor - nemcsak hazánkban - az ügyfélpénzeket nem kezelő, ezért kevésbé szigorúan szabályozott pénzügyi vállalkozások refinanszírozásán a hitelintézetek jelentős veszteségeket szenvedtek el.

A probléma kezelése érdekében, az Európai Bankhatóság külön irányelvben ( $E B A$ 2016)² szabályozta nem csak a pénzügyi vállalkozásokkal, hanem a szabályozott hitelintézeteknek az úgynevezett árnyékbankrendszerrel szemben fennálló kitettségeinek mérését, jelentését, valamint minimumkövetelményeket fogalmazott meg a kapcsolódó kockázatkezelési folyamatokkal szemben. Az EBA irányelvét a hazai szabályozás ajánlás formájában honosította meg, 2017. január 1-i hatállyal (MNB 2016a).

Mind az EBA, mind az MNB árnyékbanki, ezen belül pénzügyi vállalkozásokra vonatkozó szabályozása kiemelt kockázatként értékeli, hogy a pénzügyi vállalkozások

${ }^{1}$ CRR (Regulation (EU) No 575/2013 of the European Parliament and of the Council of 26 June 2013 on prudential requirements for credit institutions and investment firms and amending Regulation (EU) No 648/2012): 395 (5) paragrafus. In: Official Journal of the European Union, 27.6.2013. https://eur-lex.europa. eu/legal-content/EN/TXT/PDF/?uri=CELEX:32013R0575\&from=EN. Letöltés ideje: 2017. január 3.

2 EBA (2016): Limits on exposures to shadow banking entities which carry out banking activities outside a regulated framework under Article 395(2) of Regulation (EU) No. 575/2013. EBA/GL/2015/20 https://www. eba.europa.eu/documents/10180/1310259/EBA-GL-2015-20+GL+on+Shadow+Banking+Entities_EN.pdf. Letöltés ideje: 2017. január 3. 
esetében - részben az enyhébb szabályozás okán - jellemző a rövid forrásból gazdálkodás, a magas tőkeáttétel miatti sérülékenység, előfordulhat részleges tulajdonosi átfedés a refinanszírozó hitelintézettel, ugyanakkor krízishelyzetben a nyújtott források gyors kivonása, a hitelkeretek lezárása a jellemző. Az előbbiekben bemutatott kockázatok kezelése érdekében az EBA irányelv és az MNB ajánlás elvárja, hogy az intézmények második pilléres kockázatkezelési folyamataik és tőketervezésük során vegyék figyelembe, a felügyelt hitelintézet irányító testületei legyenek tudatában a felvállalt kockázatoknak, (a kapcsolódó kockázati étvágy és limitek feletti) jóváhagyásukkal vállaljanak felelősséget azokért. Végül, a belső kockázatmérési- és kezelési folyamatok fejlettségétől függően, az intézmény vagy saját maga állapíthat meg limiteket, vagy a nemzetközi szabályozásban rögzített, nagykockázat vállalásra vonatkozó limiteket (CRR 2013) kell mindenkor betartania.

Az EBA készített egy jelentést (EBA 2014) ${ }^{4}$, amely a bankokhoz hasonló tevékenységet folytató, ugyanakkor a hitelintézetekre vonatkozó európai uniós jogszabályokon kívül eső intézmények tekintetében információval szolgál a nemzeti szabályrendszerekről. Ennek alapján megállapítható, hogy a magyar pénzügyi vállalkozásokhoz hasonló tevékenységet végző intézmények engedélyezése és felügyelési gyakorlata országonként igen eltérő, a szabályozás nagyban függ attól, hogy az egyes hatóságok mit ítélnek kockázatos tevékenységnek, illetve milyen rossz tapasztalatokat, folyamatokat azonosítottak a válság hatására.

A magyar jogszabályok alapján a pénzügyi vállalkozások mind prudenciális, mind fogyasztóvédelmi oldalról felügyeltek. Tekintettel arra, hogy a pénzügyi vállalkozások a jogszabályok alapján ügyfélbetétet nem gyújthetnek, azok egyedi, intézményi szintű felügyelésében - az ügyfélérdekeknek az elsődleges szem előtt tartása érdekében - főként a fogyasztóvédelmi kockázatok előrejelzése és kezelése felé tolódott a hangsúly az elmúlt időszakban. A pénzügyi vállalkozások prudenciális felügyelése emellett leghatékonyabban - az előzőknek megfelelően - a tulajdonos vagy refinanszírozást nyújtó bankokon keresztül valósulhat meg.

Bár a hazai hitelintézetek kitettségében nem jelenik meg akkora súllyal a szektor, hogy árnyékbankrendszer felépüléséről lehetne beszélni, ahogy korábban említettük, a válság éveiben a bankok jelentős veszteségeket szenvedtek el a refinanszírozott pénzügyi vállalkozások pénzügyi helyzetének romlása következtében. Jelen tanulmány emiatt elsősorban a hazai hitelintézetek figyelmét kívánja felhívni egy, az általunk bemutatott modellhez hasonló elven múködő minősítő rendszer kialakításának lehetőségére, amely elősegítheti a pénzügyi vállalkozási szektor prudens

${ }^{3}$ CRR 2013 In: Official Journal of the European Union, 27.6.2013. https://eur-lex.europa.eu/legal-content/ EN/TXT/PDF/?uri=CELEX:32013R0575\&from=EN. Letöltés ideje: 2017. január 3.

${ }^{4}$ EBA (2014): Report to the European Commission on the perimeter of credit institutions established in the Member States. http://www.eba.europa.eu/documents/10180/534414/2014+11+27+-+EBA+Report++Credit+institutions.pdf. Letöltés ideje: 2017. január 3. 
finanszírozását. Ezzel összefüggésben elemzésünk fókuszából kikerültek a Magyarországon bejegyzett bankcsoportok tulajdonában álló pénzügyi vállalkozások, tekintettel arra, hogy finanszírozásuk, illetve kockázati monitoringjuk eltérő keretek között valósulhat meg, és a 2.2.2. fejezetben részletezett okokból a negatív események esetükben kevésbé valószínúek.

\subsection{A pénzügyi vállalkozási szektor jellemzői}

A magyar piacon múködő pénzügyi vállalkozások legjellemzőbb tevékenységi körei: a hitelnyújtás, a pénzügyi lízing, a folyó faktoring, illetve a követeléskezelésre megvásárolt faktoring (work-out) tevékenységek, amelyeket a pénzügyi vállalkozások sok esetben vegyesen végzik. (MNB 2016b, 2017, 2018). A szektor a kilencvenes évek végétől gyors ütemű növekedést mutatott mind az intézmények darabszámát, mind az összesített mérlegfőösszeget tekintve, amelynek következtében a 2005. évet követően a szegmens egésze mind mérlegfőösszegét, mind követelésállományát tekintve hazai középbanki méretet ért el. A 2009-ben elmélyülő válság következtében azonban a korábbi növekedés megtorpant (1. táblázat).

Bruttó követelésállomány szerinti eloszlást tekintve továbbra is elsősorban a hitelezés dominál a pénzügyi vállalkozások körében, ezt követi a lízing (MNB 2018). Figyelemreméltó tendencia ugyanakkor, hogy míg e két típusba tartozó követelésállomány csökkent, a megvásárolt lejárt követelések állománya a válság óta jelentős növekedést mutat a bankcsoporthoz nem tartozó pénzügyi vállalkozások teljes szektorát tekintve (MNB 2016b, 2017, 2018).

A válság hatására a refinanszírozók által elszenvedett veszteségek következtében a hitelintézeti szektor fokozatosan kivonulni látszik a pénzügyi vállalkozások finanszírozásából, megnehezítve ezen intézmények forráshoz jutását. Ezzel párhuzamosan a hitelintézetek portfóliótisztítási folyamatának részeként igyekeznek a lejárt követeléseiket értékesíteni, így az utóbbi években alakult pénzügyi vállalkozások is jellemzően elsősorban lejárt követelések vásárlására nyújtottak be tevékenységi engedély kérelmet (MNB 2016b), illetve a kizárólag e tevékenységet folytató intézmények száma is növekedett (MNB 2017, 2018). Részben a fenti folyamatoknak, illetve az európai uniós támogatásoknak köszönhető, hogy a válság hatására sem csökkent drasztikusan a pénzügyi vállalkozások száma, inkább stagnálás, a szektor tisztulása után pedig az elmúlt néhány évben ismét enyhe növekedés figyelhető meg.

A nem bankcsoporthoz tartozó pénzügyi vállalkozások forrásszerkezetét vizsgálva megállapítható, hogy a banki finanszírozás lényegében lekövette az általános hitelezési trendeket, a válságidőszakban jelentősen csökkenő, majd az elmúlt évben ismét növekvő forráskihelyezéssel (MNB 2016b, 2017, 2018). Az 1. ábrán az is látható, hogy az általános gazdasági fellendülést lekövetve, a hazai hitelintézeti refinanszírozás már az elmúlt két év folyamán növekvő trendet mutatott, amely elsősorban a work-out tevékenységet folytató pénzügyi vállalkozási kört érintette 
(MNB 2018). Nagyságrendjében a pénzügyi vállalkozások részére kihelyezett hitelállomány szektorszinten nem tekinthető magasnak, ugyanakkor, tekintettel annak emelkedő trendjére, a folyamat mind üzleti, mind kockázati szempontokat tekintve is figyelmet érdemel. Az egyéb források alakulásából látható, hogy a válság utáni években (főként tulajdonosi finanszírozás által) a pénzügyi vállalkozások csak részben tudták kompenzálni a kieső hitelintézeti forrásokat, azonban az utóbbi két évben már az egyéb források csökkenő mértéke mellett is növekedni tudott a szektor mérlegfőösszege. Bár a saját tőke állománya 2012 óta növekedett, és ezzel párhuzamosan a tőkeellátottság is javult, ez elsősorban egy-egy nagyobb (lakossági hitelnyújtási, illetve a work-out tevékenységgel foglalkozó) intézmény eredményes müködésén alapult.

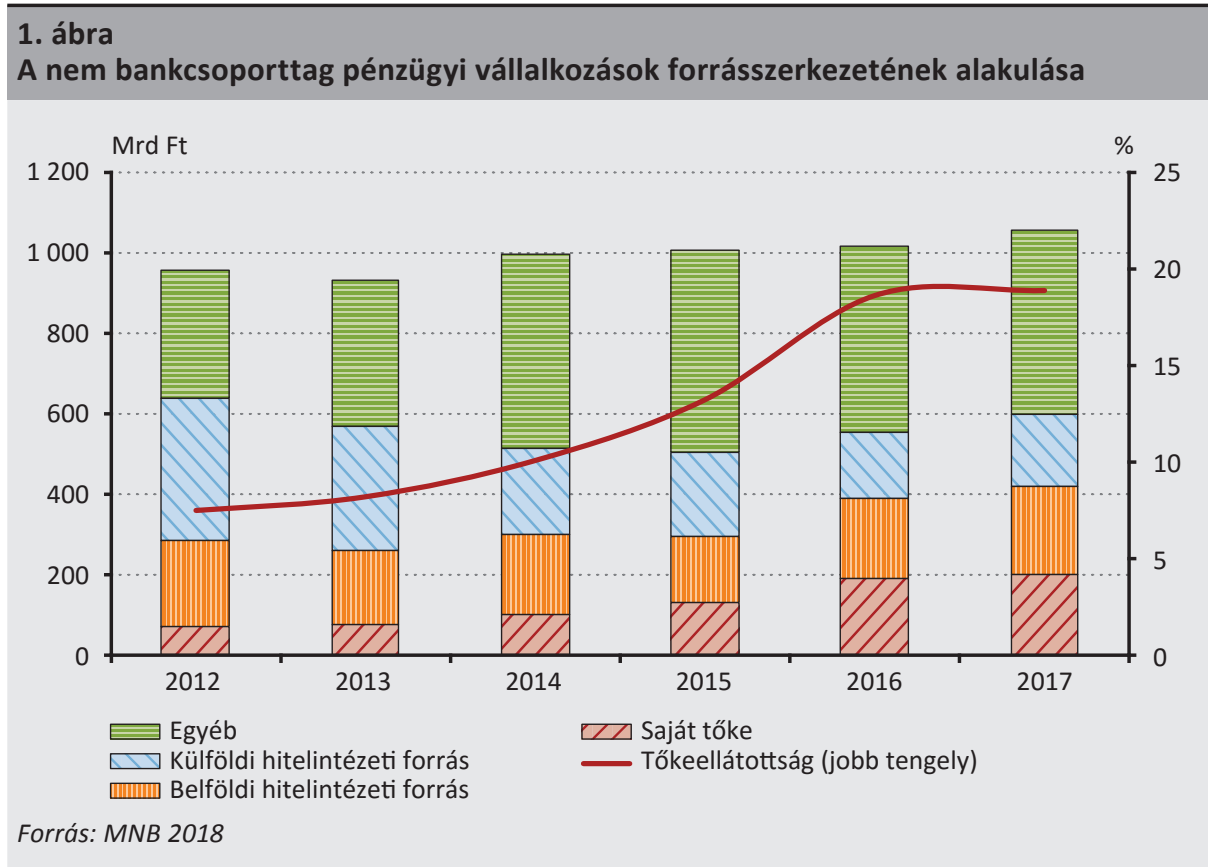

A méreteloszlást tekintve, a pénzügyi vállalati szektor nemcsak a végzett tevékenységi körök, hanem az intézmények mérlegfőösszegének vonatkozásában is igen heterogén, a 10 legnagyobb - nem bank- vagy egyéb intézménycsoportba tartozó - intézmény 50 százalék körüli piaci részesedéssel rendelkezik. A legnagyobb piaci szereplők jellemzően tőkeerős, külföldi tulajdonosi háttérrel rendelkező pénzügyi vállalkozások, emellett számos kisebb, általában hazai tulajdonban lévő intézmény múködik (MNB 2017). A néhány nagyobb, illetve számos kisebb intézményt magában foglaló piac szerkezetét jól szemlélteti, hogy a 2017. év végén a legnagyobb mérleg szerinti eredményt elérő 5 intézmény a vizsgált szektor eredményének 80 
százalékát tette ki (MNB 2018). A piac összetételének, illetve a teljes magyar bankszektorhoz képest elhanyagolható méretének köszönhető, hogy egyedi mozgások (pl. nagyobb intézmény piacról történő kivonulása, nagyobb banki követeléscsomag vagy korábbi bankcsoporthoz tartozó pénzügyi vállalkozás eladása) jelentős változásokat eredményezhetnek a teljes mérlegfőösszeg - és sok esetben a bankcsoportok részéről nyújtott finanszírozás - alakulásában.

A szektor heterogenitásából kifolyólag a kockázatok is igen eltérőek lehetnek az intézmények mérete és tevékenységük jellege függvényében. Kisebb pénzügyi vállalkozásoknál megfigyelhető, hogy a tulajdonosi források kimerülése, illetve refinanszírozók bevonásának sikertelensége esetén sokszor nem tudják elérni azt az üzemméretet, amely az eredményes müködésükhöz szükséges lenne, így a piacról való kilépés mellett döntenek, vagy tevékenységi engedélyük visszavonásra kerül, mivel a saját tőkére vonatkozó, illetve egyéb, prudens múködéshez szükséges jogszabályi feltételeknek nem tudnak megfelelni. A pénzügyi válságot követően továbbá több intézmény esetén láthattunk példát arra, hogy a jelentős tőkeáttétel és nem megfelelő refinanszírozói kontroll mellett működő, nem kellően körültekintő hitelezési politikát folytató pénzügyi vállalkozások az elszenvedett veszteségek következtében felszámolás alá kerültek. A késedelmes követeléseket vásárló pénzügyi vállalkozások kockázatai előbbi (hitelezéssel foglalkozó) intézményekkel nehezen összevethetők, hiszen esetükben elsősorban a bedőlt portfóliók pontos értékelésén, a megfelelő szaktudással rendelkező behajtási szakértők alkalmazásán, illetve a költséghatékony múködési modell kialakításán múlik az eredményesség.

A fentiek alapján megfontolandó lehet az eltérő kockázati sajátosságokkal rendelkező intézményekre különböző kockázati monitoring-modelleket kialakítani, amelyet elsősorban a mintaelemszám jelentős csökkenése miatt vetettünk el. Ugyanakkor szükségesnek tartjuk felhívni a figyelmet arra, hogy a következőkben bemutatásra kerülő modell megbízhatósága ellenére, az intézmények esetenként jelentősen eltérő üzleti modelljére tekintettel a monitoring eszközt elsősorban az egyedi szakértői értékelések kiegészítéseként tartjuk hatékony eszköznek a refinanszírozói kockázatok nyomon követésére.

\subsection{Indokok a szegmens kockázati monitoringja mellett}

A pénzügyi vállalkozások szegmense méretéből adódóan a korábban látottak szerint jelenleg nem jelent rendszerkockázatot, legalábbis olyan mértékben semmiképpen sem, mint némely nyugat-európai gazdasági rendszerben - európai példaként Hollandiát említhetjük (Broos et al. 2012). Mindazonáltal, ahogy arra a bevezetóben is utaltunk, az előző évtizedben a pénzügyi vállalkozások mind számosságukban, mind kockázatvállalásban jelentősen terjeszkedtek. E szektorban is elsősorban a 2008ban kezdődő pénzpiaci válság mutatott rá a korábbiakban felépült kockázatokra, a következők szerint: 
- visszautalva az előző pontban bemutatott hitelezési folyamatokra, a Magyarországon bejegyzett közép- és nagybankok számos esetben refinanszíroztak elégtelen kockázatkezeléssel rendelkező, lakossági, vállalati hitelezéssel vagy faktoring tevékenységgel foglalkozó pénzügyi vállalkozásokat, jelentős veszteségeket elszenvedve ezen ügyleteken;

- több részpiacra - így például a lakossági jelzálog-, valamint lízing hitelpiacokra sok esetben elégtelen szaktudással és háttérrel, nem kellően végiggondolt üzleti modellel és hitelezési folyamatokkal léptek be pénzügyi vállalkozások, hozzájárulva a válság előtt megfigyelhető rossz hitelezési gyakorlatok elterjedéséhez;

- végül, az előző ponthoz kapcsolódóan, sok esetben fogyasztóvédelmi tekintetben is rossz gyakorlatok elterjedése indult meg egyes pénzügyi vállalkozásokhoz köthetően.

Az előzőekben felvázolt kockázatok az elmúlt néhány évben jelentősen mérséklődtek, részben a Magyar Nemzeti Bank a túlzott lakossági hitelkiáramlást megakadályozó makroprudenciális szabályozása (azaz a jövedelemarányos törlesztő részletet, valamint a hitelfedezeti mutatót korlátozó rendeletek, amelyek a pénzügyi vállalkozásokra is kötelező érvényúek), részben a szektor tisztulása következtében.

Mindazonáltal az mindenképpen vizsgálatot érdemel, hogy a válságidőszakban a nem bankcsoporttag pénzügyi vállalkozásokra kalibrált kockázati monitoring eszköz a tisztább szabályozói háttér és erősebb felügyelés mellett is megfelelően teljesít-e. Amennyiben igen, abban az esetben addicionális eszközként szolgálhat a potenciálisan refinanszírozott pénzügyi vállalkozások kockázatainak, gazdasági erejének, életképességének a felmérése, nyomon követése érdekében. A következőkben tehát egy egyszerű, jelzőlámpa-rendszerű stabil monitoring eszközt mutatunk be, amely kockázati szegmensekbe sorolja be a hazánkban tevékenykedő, nem bankcsoporttag pénzügyi vállalkozásokat.

\section{Monitoring-modell magyar pénzügyi vállalkozásokra}

\subsection{A szegmens kockázati jellemzői}

Amint azt jelen tanulmány 1.2. alrészében bemutattuk, a pénzügyi vállalkozások mint pénzintézeti szegmens fölfutása a kilencvenes évek végére, de leginkább a következő évtized közepére tehető. Az ezt követő válságévekben a pénzügyi vállalkozások, a hazánkban aktív hitelintézetekhez hasonlóan, jelentős mérlegalkalmazkodást („deleveraging”) hajtottak végre, részben természetesen a hitelintézeti refinanszírozási források szúkülése miatti kényszerből.

A pénzügyi vállalkozások követelésállományának jelentős növekedésével párhuzamosan a szegmens kockázatai is lényegesen növekedtek (1. táblázat). Megfigyelhető, hogy a negatív eseményráta (azaz az adott évi beszámoló fordulónapja utáni egy 
évben bekövetkező felszámolás, csődeljárás, bírósági törlés, befejezett felszámolás, kényszer-végelszámolás) a szegmens mérlegfőösszegének, követelésállományának növekedésével, a 2009-ben elmélyülő válság utáni követelésminőség-romlás miatt jelentősen emelkedett, majd a 2012. évi gazdaságpolitikai konszolidációt, valamint a nem fenntartható üzleti modellel rendelkező pénzügyi vállalkozások megszűnését követően fokozatosan csökkent a szektor egészének kockázata.

\section{1. táblázat}

\section{Áttekintés a nem bankcsoporttag pénzügyi vállalkozások szegmenséről és kockázati} jellemzőiről

\begin{tabular}{|c|c|c|c|c|c|}
\hline $\begin{array}{c}\text { NAV beszámoló } \\
\text { éve }\end{array}$ & $\begin{array}{c}\text { PV-k száma } \\
\text { (nem-banki, db) }\end{array}$ & $\begin{array}{l}\text { Negatív } \\
\text { esemény } \\
\text { (db) }\end{array}$ & $\begin{array}{l}\text { Negatív } \\
\text { esemény ráta } \\
\text { (1 éves, \%) }\end{array}$ & $\begin{array}{c}\text { Mérlegfőösszeg } \\
\text { (mrd Ft) }\end{array}$ & $\begin{array}{c}\text { Követelés- } \\
\text { állomány } \\
\text { (mrd Ft) }\end{array}$ \\
\hline 1992 & 8 & 0 & $0,00 \%$ & 3 & 1 \\
\hline 1993 & 10 & 0 & $0,00 \%$ & 21 & 2 \\
\hline 1994 & 11 & 0 & $0,00 \%$ & 28 & 3 \\
\hline 1995 & 11 & 0 & $0,00 \%$ & 36 & 5 \\
\hline 1996 & 15 & 0 & $0,00 \%$ & 52 & 24 \\
\hline 1997 & 38 & 0 & $0,00 \%$ & 70 & 35 \\
\hline 1998 & 49 & 0 & $0,00 \%$ & 107 & 68 \\
\hline 1999 & 83 & 0 & $0,00 \%$ & 122 & 88 \\
\hline 2000 & 106 & 0 & $0,00 \%$ & 142 & 112 \\
\hline 2001 & 118 & 0 & $0,00 \%$ & 177 & 137 \\
\hline 2002 & 123 & 0 & $0,00 \%$ & 224 & 165 \\
\hline 2003 & 135 & 0 & $0,00 \%$ & 325 & 250 \\
\hline 2004 & 157 & 2 & $1,27 \%$ & 464 & 325 \\
\hline 2005 & 166 & 1 & $0,60 \%$ & 562 & 459 \\
\hline 2006 & 184 & 1 & $0,54 \%$ & 724 & 545 \\
\hline 2007 & 201 & 4 & $1,99 \%$ & 940 & 730 \\
\hline 2008 & 211 & 1 & $0,47 \%$ & 1273 & 980 \\
\hline 2009 & 213 & 1 & $0,47 \%$ & 1146 & 850 \\
\hline 2010 & 212 & 4 & $1,89 \%$ & 1302 & 1006 \\
\hline 2011 & 212 & 6 & $2,83 \%$ & 1224 & 938 \\
\hline 2012 & 213 & 4 & $1,88 \%$ & 1225 & 774 \\
\hline 2013 & 220 & 4 & $1,82 \%$ & 1146 & 717 \\
\hline 2014 & 223 & 2 & $0,90 \%$ & 1192 & 881 \\
\hline 2015 & 215 & 0 & $0,00 \%$ & 1339 & 816 \\
\hline 2016 & 220 & 1 & $0,45 \%$ & 1370 & 788 \\
\hline
\end{tabular}

Megjegyzés: Barna szín jelöli a fejlesztési (2004-2011 NAV-beszámoló évek), világoskék a validációs (2002-2014 NAV-beszámoló évek) mintát. Végül zöld szín jelöli az időkizárt tesztmintát (2016 NAV-beszámoló év).

Forrás: A NAV és az Opten adatbázisa alapján számítva 
A jelen tanulmány korábbi alrészeiben bemutatottak szerint, várakozásunk alapján a szabályozói és működési környezetből következően nem elsődlegesen a tőke, hanem a likviditási, refinanszírozási és forrásmegújitási kockázatok lesznek azok, amelyek erősen magyarázzák a pénzügyi vállalkozások múködési nehézségeit. További, szabályozásból következő kockázat a korlátozott mértékben diverzifikálható üzleti modell kockázata, hiszen például az ügyfélpénzek kezelésének tilalma korlátozott mértékben teszi lehetővé a bevételi források szerkezetének átalakítását. Végezetül, a pénzügyi vállalkozások csaknem minden modern pénzügyi rendszerben marginális, „niche” szereplők, azaz jelentős hitelkockázatot kényszerülnek futni amiatt, hogy néhány kivételtől eltekintve a nagyobb szereplők által elutasított ügyfeleket kénytelenek finanszírozni. A későbbiekben részletesen bemutatjuk, hogy ezen közgazdasági várakozásokat az elsődlegesen adatvezérelt fejlesztés hogyan és mennyiben igazolta vissza.

\subsection{Alkalmazott szegmentációs és modellezési gyakorlat}

\subsubsection{Szakirodalmi áttekintés}

A pénzügyi vállalkozások refinanszírozási és hitelkockázatát a felügyelt intézmények, valamint a nemzetközi hitelminősítők többnyire a banki, biztosítói, esetleg befektetési alapokkal közös mintán fejlesztett és nyomon követett minősítő rendszerrel mérik fel. A követett gyakorlat szükségképpen vagy azt eredményezi, hogy a modellt végül külön kalibrálják az egyes alszegmensekre, vagy, egyszerúsítve, a lehető legáltalánosabb megközelítésre törekedve, néhány fő mérleg- és eredményváltozóra alapozva fejlesztik. Ezen modellezési megközelítések között említhetjük a Moody's modelljét (Hill - Auquier 2014), amelyben makrogazdasági változók mellett többek között tőke- és eszközarányos megtérülés, mérlegföösszeg, valamint különböző likviditási mutatók szerepelnek magyarázó változóként. A felhasznált változókat tekintve hasonló, de némileg eltérő szerkezetű a Standard and Poor's pénzügyi intézményekre és biztosítókra kifejlesztett minősítő rendszere (Tripolitakis et al. 2015), amely három modult, azaz az üzleti kockázatokat, a pénzügyi kockázatokat, valamint a hitel-, piaci és likviditási kockázatokat súlyozza össze egy végső minősítéssé. Végül említést érdemel, hogy a bázeli Nemzetközi Fizetések Bankja (BIS) több elemzésben is kiemelten foglalkozott a hitelintézetek minősítésének nehézségeivel, kiemelve a makrogazdasági környezet és a szabályozói körülmények, így például az állami segítségnyújtásnak vagy elmaradásának szerepét (lásd például Packer-Tarashev 2011).

Hazai előzmények tekintetében elmondható, hogy kifejezetten hitelintézetekre, pénzügyi vállalkozásokra kidolgozott minősítő rendszer publikálására még nem került sor, ezért jelen tanulmány a bevezetőben jelzetteknek megfelelően e tekintetben úttörőnek számít. Ebből következően ehelyütt csak röviden tekintjük át a vállalati csőd- és nem-fizetési kockázatok elemzésével, modellezésével kapcsolatban hazánkban született publikációkat, hiszen e modelleket, megközelítéseket 
kifejezetten nem-pénzügyi vállalkozásokra dolgozták ki, és alkalmazhatóságuk pénzügyi vállalkozásokra, hitelintézetekre nem képezte vizsgálat tárgyát - feltehetően nem is volnának alkalmasak a pénzügyi vállalkozások kockázatainak igazán pontos elemzésére. A teljesség igénye nélkül, Hajdu - Virág $(1996,2001)$ mutatta be a hazai kis- és középvállalkozások nem-teljesítési kockázatának becslésére kidolgozott módszertanát. A Bázel II követelmények közül a minél pontosabb szeparáló erő elérése mint cél kerül kibontásra Kristóf (2008) publikációjában. Végezetül, az MNB szakértői vállalati hitelkockázati témakörben az elmúlt években több megközelítést is ismertettek, ezek közül Banai et al. (2013), valamint Bauer - Endrész (2016) publikációit említjük.

Tekintettel arra, hogy a pénzügyi vállalkozások szegmense szabályozás, múködés, üzleti modell szempontjából sok tekintetben a hitelintézetektől lényegesen eltérő jellemzőkkel írható le, jelen tanulmány szerzői kizárólag a nem bankcsoporttag pénzügyi vállalkozások mintáján fejlesztették az alábbiakban részletesen bemutatott monitoring eszközt.

\subsubsection{A magyar pénzügyi vállalkozási szegmensen alkalmazott modell}

A bankcsoporttag pénzügyi vállalkozások modellből történő kizárása mögött az a közgazdasági megfontolás, azaz az a megfigyelés húzódik meg, hogy egy pénzügyi-hitelintézeti vállalatcsoport reputációs kockázati okokból sokkal kevésbé engedheti meg, hogy egy - különösen ugyanazon ország piacán múködő - tartósan veszteséges leányvállalata felszámolási (vagy egyéb negatív konnotációjú) jogi eljárás alá kerüljön, mint egy egyéb tulajdonos által üzemeltett pénzügyi vállalkozás. Ezenfelül a hitelintézeti csoportokon belüli pénzügyi vállalkozások sok esetben az adott intézménycsoport tőke- és likviditásmenedzsmentjének optimalizálása érdekében kerülnek létrehozásra, azaz teljesen más céllal, mint a nem bankcsoporttag pénzügyi vállalkozások. Végül, az utóbbi néhány évben, főként költségszinergiák megteremtése érdekében több bankcsoport a csoportba tartozó pénzügyi vállalkozásainak csoportvezető intézménybe való beolvasztása mellett döntött, azaz egy kockázati jellemzőktől lényegében független átrendeződés figyelhető meg e szegmens esetében.

A modell felépítését megelőzően megfontoltuk a pénzügyi vállalkozások mögötti hitelportfólió minőségének közvetlen mérését mint lehetőséget, ezt azonban több okból kifolyólag is elvetettük. Egyrészt azért, mert a pénzügyi vállalkozások által az MNB részére teljesítendő rendszeres jelentések a kezelt követelésállományról alapvetően aggregált adatokat tartalmaznak, granulált adatok csak rövidebb időtávra állnak rendelkezésre, és nem tartalmazzák a portfólióminőség megítéléséhez szükséges információkat. Másrészt azért, mert az esetek többségében ezen információkhoz a pénzügyi vállalkozásokat refinanszírozó pénzintézetek sem férnek hozzá, erre - jellemzően - nem rendszeresen, hanem akvizíciót megelőző portfólió-átvilágítás keretében szokott sor kerülni. Végül, a work-out tevékenységet végző pénzügyi vállalkozások kockázatainak mérésére egy ilyen modell alkalmatlan lenne. 
Megfontolható lehet ezenfelül az MNB felé teljesítendő adatszolgáltatásokban szereplő mérleg- és eredménykimutatás adatait felhasználni a minősítő modell fejlesztésére, tekintettel arra, hogy azok a Nemzeti Adó- és Vámhivatal (NAV) és az Opten adatbázisában szereplő beszámolók struktúrájához képest jobban tükrözik a vizsgált intézmények által végzett pénzügyi szolgáltatási tevékenység jellegét. A modell kialakításkor ugyanakkor az volt a célunk, hogy bemutassuk, a hitelintézetek számára hozzáférhető mérlegadatok alapján is felépíthető lehet egy megbízható monitoring-modell a refinanszírozói kockázatok mérésének támogatására.

A monitoring eszköz fejlesztése során ennek megfelelően a NAV vállalati adatbázis mérleg- és eredménykimutatás-adatait, valamint - kimeneti, a kockázatot, negatív eseményt jelző változóként - az Opten-adatbázis negatív esemény regiszterét használtuk fel. Az 1. táblázatban bemutatottak szerint a fejlesztési minta a 2004-2011-es évek NAV-beszámolói voltak, míg validációra a 2012-2014-es évek NAV-beszámolóit használtuk fel, mert ezekben az években fordultak elő egyáltalán negatív jogi események a szegmensben. Végezetül, minden egyes pénzügyi vállalkozást addig az időpontig szerepeltettünk a mintában, ameddig NAV-beszámolót adott le, vagy az első negatív esemény bekövetkezett, azaz - a ténylegesen megfigyeltekkel összhangban - nem számoltunk felszámolási / csőd- / stb. eljárásból, azaz negatív jogi eseményből történő visszatéréssel. További lényeges, a későbbiekben ismertetett modellezési lépés volt, hogy a minősítés hozzárendelésénél azon pénzügyi vállalkozások esetében, amelyek még léteztek az adott évben, de nem adtak le NAV-beszámolót a negatív eseménnyel történő megszűnésükig, az utolsó fennállási évhez (tehát az utolsó NAV-beszámoló fordulónapjától számított egy év) rendeltük a negatív esemény bekövetkezési időpontját. Ezzel szemben, a nem-teljesítési valószínűség kalibrációjánál és a minősítés hozzárendelése esetében a NAV-beszámolóval nem rendelkező pénzügyi vállalkozások a legrosszabb teljesítő minősítést kapják meg. Amint látni fogjuk, egyik eljárás sem okozott torzítást a monitoring eszköz fejlesztése (és felhasználása során), utóbbi, azaz a hiányzó beszámoló miatti minősítésrontás pedig összhangban van a felügyelt intézmények minősítés-hozzárendelési gyakorlatával (azaz ún. „override” gyakorlattal a vállalkozásra vonatkozóan ismert negatív információ esetén).

A monitoring eszköz kialakítása során logisztikus regressziót használtunk abból a megfontolásból, hogy közgazdaságilag (log)lineáris, azaz változónként monoton növekvő kockázat az intuitív, továbbá attól eltérő hatások megbízható mérését az alacsony mintaelemszám nem teszi lehetővé. A változószelekció és a logisztikus regresszió súlyainak becslése teljes egészében a fejlesztési mintán, azaz a 2004-2011. évi NAV-beszámolók alapján történt, a validációs mintát kizárólag időkizárt viszszamérésre használtuk fel. Ezen a módon a fejlesztési és a validációs minta aránya hozzávetőleg 70-30 százalék, ami modellvalidációs szempontból megfelel a szakirodalomban ismertetett jó gyakorlatnak (Hastie et al. 2008). 


\section{Frekventista paraméterbecslés}

A modellezés során az előző alrészben ismertetett módon, a fejlesztési mintán (2004-2011. évi NAV-beszámoló) a logisztikus regresszió paramétereit a szakirodalomban ismert „maximum likelihood” módszerrel becsültük, az alábbi kifejezés maximalizálásával (Agresti 1990):

$$
L(\text { adatok } \mid \theta)=\sum_{i=1, y_{i}=1}^{N} \log P\left(x_{i}\right)+\sum_{i=0, y_{i}=0}^{N} \log \left(1-P\left(x_{i}\right)\right),
$$

ahol $\log P\left(x_{i}\right)$ az adott kategóriajelző bekövetkezési valószínűségének logaritmusa a magyarázó változók felvett értékének függvényében, minden megfigyelésre $(N)$ összegezve.

A változószelekció során első lépésben a fejlesztési minta NAV-beszámolói (mérleg- és eredmény-kimutatás) minden egyes változójának rangsorolási erősségét vizsgáltuk meg, majd második lépésben a fejlesztési mintán legerősebb változókból képeztük a közgazdasági logikának megfelelő és a mérni kívánt kockázatokat leginkább lefedő összetett változókat. Az összetett változók képzése során kiemelt szempont volt, hogy az azokkal létrehozott modell teljesítménye ne legyen gyengébb a legerősebb egyedi változókkal kapott rangsorolási erőnél. Végül az összetett változók esetében a kilógó értékek kezelését - hasonlóan a vállalati monitoring eszköz esetében alkalmazottakhoz - logaritmizálással kezeltük ${ }^{5}$, valamint a megfelelő módszerrel (Liao - McGee 2003) elvégeztük a változók sztenderdizálását (Hong - Ryu 2006), azaz a relatív erősségük megállapítását is. Az e szempontok és eljárások alapján becsült modellt mutatja be a 2. táblázat.

\footnotetext{
${ }^{5}$ Az összes összetett változó esetében $(x)$ a következő transzformációt végeztük el: asinh(x/2), amely közelítőleg a logaritmizáláshoz hasonló.
} 


\section{2. táblázat}

A fejlesztési mintán becsült logisztikus regresszió paraméterei, leíró statisztikái, valamint a sztenderdizált súlyok

\begin{tabular}{|c|c|c|c|c|c|c|}
\hline Változó & $\begin{array}{c}\text { Becsült } \\
\text { paraméter }\end{array}$ & $\begin{array}{l}\text { Standard } \\
\text { hiba }\end{array}$ & $\begin{array}{l}\text { Szignifi- } \\
\text { kancia }\end{array}$ & Várt előjel & Kockázat & $\begin{array}{l}\text { Változók } \\
\text { sztender- } \\
\text { dizált súlya }\end{array}$ \\
\hline $\begin{array}{l}\text { ROA = Mérleg } \\
\text { szerinti eredmény / } \\
\text { Mérlegfőösszeg }\end{array}$ & $-0,3276$ & 1,0614 & 0,7575 & - & $\begin{array}{l}\text { Jövedel- } \\
\text { mezőség }\end{array}$ & $4,80 \%$ \\
\hline $\begin{array}{l}\text { Hosszú távú megté- } \\
\text { rülés = } \\
\text { (Eredménytartalék - } \\
\text { Követelések után } \\
\text { elszámolt ÉV) / } \\
\text { (Követelések könyv } \\
\text { szerinti értéke) }\end{array}$ & $-0,4150$ & 0,1024 & $5,09 e-05$ & - & $\begin{array}{l}\text { Jövedel- } \\
\text { mezőség, } \\
\text { Hitel- } \\
\text { kockázat }\end{array}$ & $27,69 \%$ \\
\hline $\begin{array}{l}\text { Rövid távú likviditás } \\
=\text { Rövid } \\
\text { kötelezettségek / } \\
\text { Pénzeszközök }\end{array}$ & 0,2292 & 0,0671 & 0,0006 & + & Likviditás & $26,98 \%$ \\
\hline $\begin{array}{l}\text { Egy FTE-re jutó } \\
\text { átlagos üzemi } \\
\text { eredmény = Üzemi } \\
\text { eredmény / Létszám }\end{array}$ & $-0,0598$ & 0,0308 & 0,0519 & - & $\begin{array}{l}\text { Jövedel- } \\
\text { mezőség, } \\
\text { Hitel- } \\
\text { kockázat }\end{array}$ & $18,25 \%$ \\
\hline $\begin{array}{l}\text { Nettó amortizációs } \\
\text { ráta = (Tárgyévben } \\
\text { üzembe helyezett } \\
\text { beruh. értéke - } \\
\text { Tárgyévben } \\
\text { elszámolt ÉCS) / } \\
\text { (Immat. javak + } \\
\text { Tárgyi eszközök) }\end{array}$ & $-0,3964$ & 0,1285 & 0,0020 & - & $\begin{array}{l}\text { Múködési } \\
\text { kockázat }\end{array}$ & $22,29 \%$ \\
\hline Tengelymetszet & $-5,6751$ & 0,4493 & $2,00 E-16$ & & & \\
\hline
\end{tabular}

Forrás: A NAV és az Opten adatbázisának 2004-2011. (NAV), ill. 2004-2012. (Opten) éveinek mintája alapján számítva.

Amint látható, a monitoring eszköz a pénzügyi vállalkozások csaknem összes releváns kockázatát méri megfelelő mutatószámmal. Az 1. mellékletben bemutatottak szerint a változók közti keresztkorreláció nem erős, azaz a kiválasztott mutatók nem ugyanazokat a kockázatokat fedik le. 


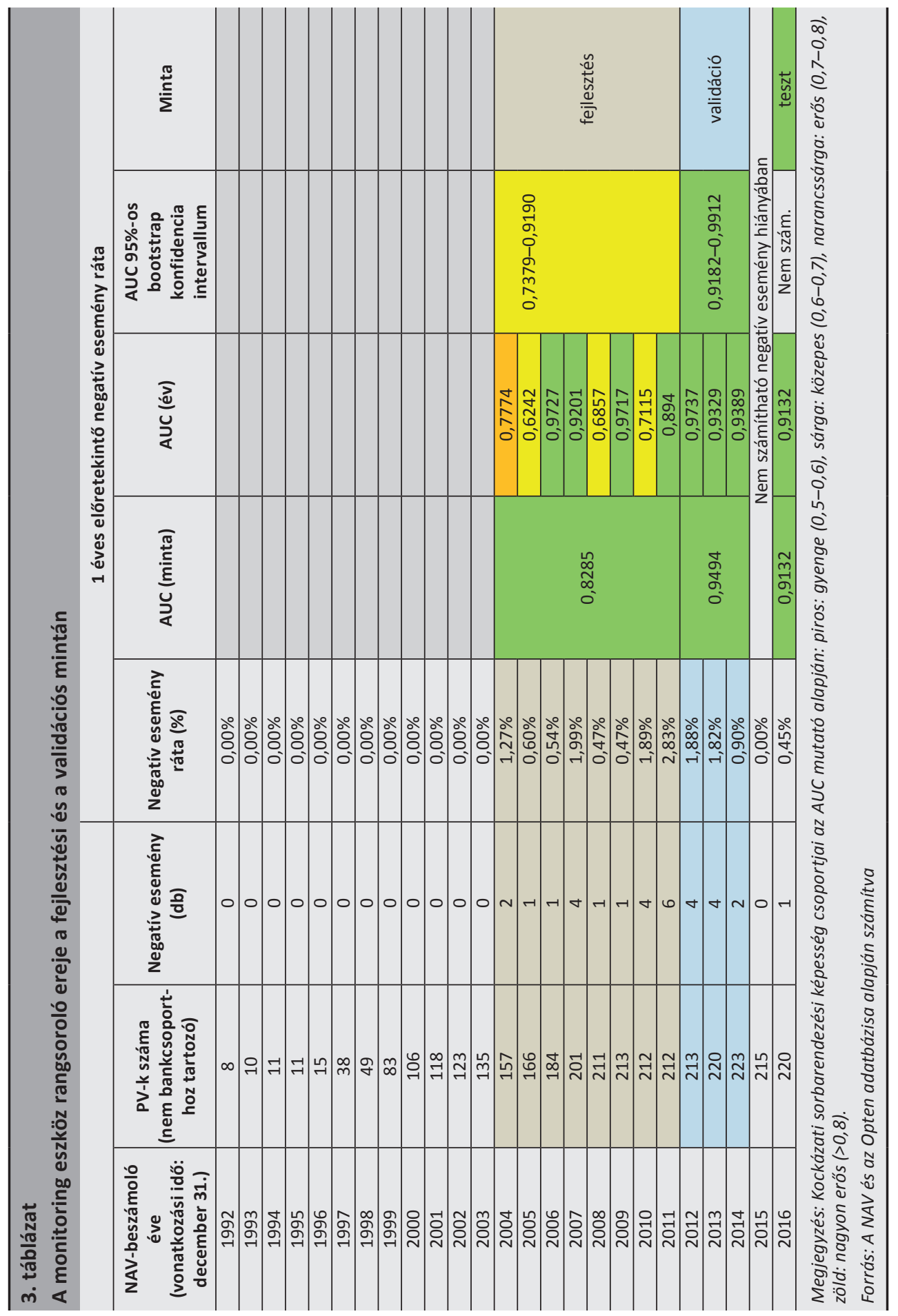


A 3. táblázat alapján a monitoring eszköz mind a fejlesztési, mind a validációs mintán kifejezetten erős rangsoroló erővel rendelkezik, még évekre lebontva is. Mindez egyben azt is jelenti, hogy stabil és rövid távon is használható a fejlesztett eszköz.

A 2. táblázat alapján továbbá lényeges közgazdasági következtetések is levonhatóak a változók különböző konstellációi esetén, például lehetséges, hogy adott évben (és adott esetben az alakulása óta eltelt években) megfelelő eredményt ért el egy pénzügyi vállalkozás, ugyanakkor, amennyiben például ezt alacsony egy munkaerőre jutó hatékonysággal, továbbá a beruházások elhalasztásával éri el, az mindenképpen kétségeket ébreszt az adott vállalkozás hosszú távú életképességével kapcsolatosan, mivel ez utóbbi két változó közép- vagy hosszú távon az adott évi, illetve a hosszú távú jövedelmezőségi mutató romlásán keresztül rontja majd az adott pénzügyi vállalkozás minősítését.

Legvégső lépésként azt is megvizsgáltuk, hogy a fejlesztési mintán döntési fa segítségével megállapított kockázati kategóriákba rendezés (Joopia 2016) stabil-e a validációs mintán is. A 4. táblázat alapján, amely a korábbiakban említettek szerint, hiányzó NAV-beszámoló esetén átsorolással kezeli a megnövekedett kockázatot, a NAV-beszámoló fordulónapja után, mind egy, mind két éves kimeneti ablakon, stabil a minősítési kategóriák szerinti kockázati rendezés. 


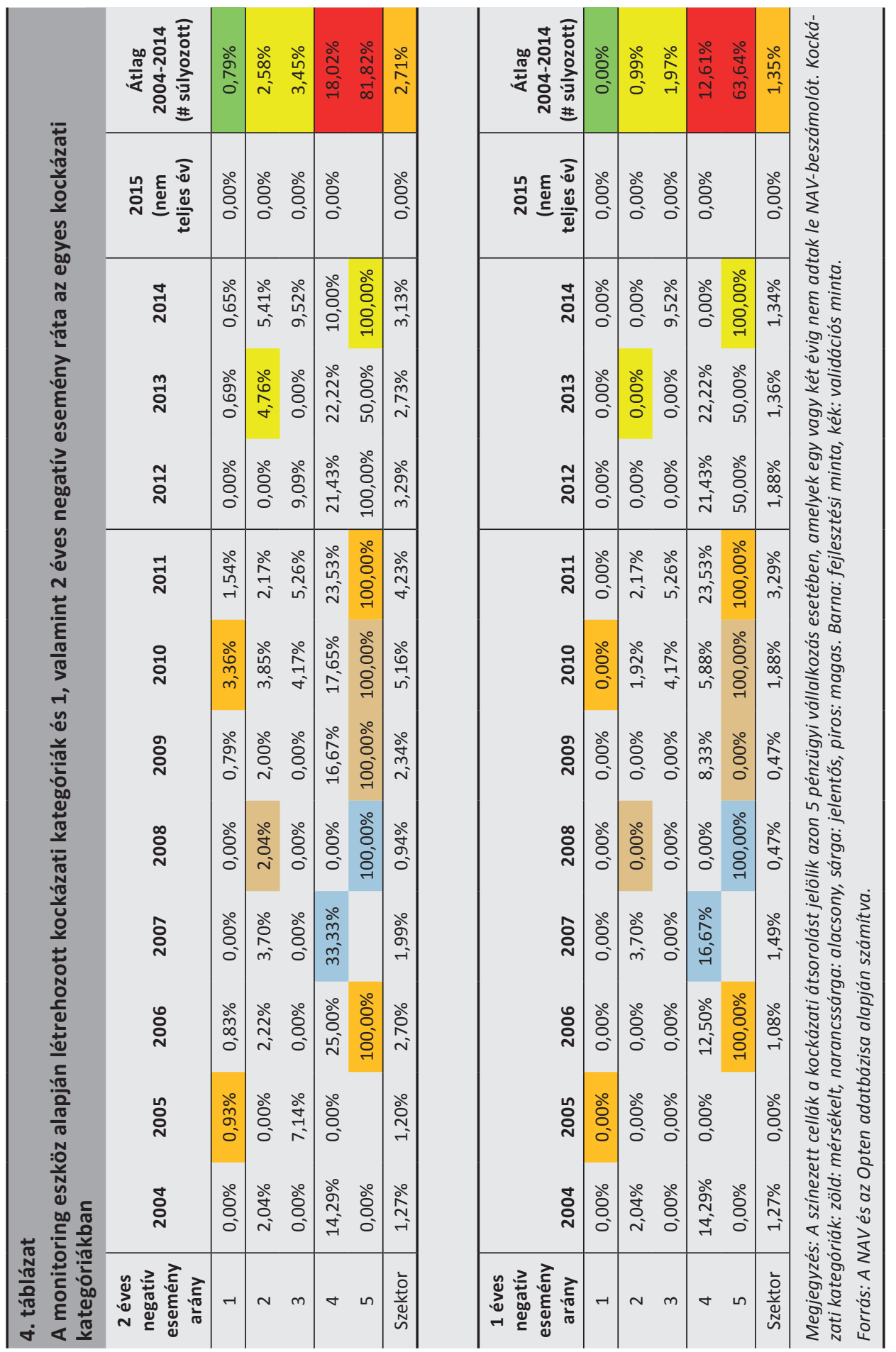


A monitoring eszköz fejlesztése során az előzőekben nem ismertetett, de lényeges szempont volt még az, hogy a minősítő rendszer minél érzékenyebben reagáljon az intézmények aktuális kockázati állapotára, azaz hogy minél jobban lekövesse az egyedi intézményi kockázatok változását. Minthogy az eszköz felhasználására az intézmények folyamatos monitoringja keretében kerülhet sor, ezért a cél tehát az intézmények aktuális helyzetének megragadása, azaz egy ciklusfüggő minősítő rendszer létrehozása.

A fenti szempontok teljesülésének vizsgálata céljából összevetettük az egyes minősítési kategóriák közötti megoszlást, valamint az előre jelzett és a ténylegesen bekövetkezett negatív esemény rátákat. Az 5. táblázat a pénzügyi vállalkozások egyes minősítési kategóriákon belüli megoszlását mutatja be. Az elemzés alapján erős, minősítési kategóriák közötti migráció látszik, amely ugyanakkor a 4. táblázatban bemutatottak szerint nem rontja a 2 éves előre tekintő besorolás rangsoroló erejét. Azaz bár az egyik évről másik évre történő minősítési kategóriák közötti migráció erős, ez az egyedi intézmények, valamint a pénzügyi vállalkozások szektorának rövid- és középtávú kockázatainak növekedésével és mérséklődésével összhangban, azokat lekövetve valósul meg. Mindez tehát azt jelenti, hogy a monitoring eszköz minősítése alapján minden évben pontos relatív (pénzügyi vállalkozások egymáshoz viszonyított kockázatossága) és abszolút (kockázatok mértéke egyedi és szektor szinten) kép nyerhető mind az egyedi vállalkozások, mind a teljes pénzügyi vállalkozási szektor kockázatosságáról. Ezen túlmenően, minthogy a minősítés kizárólag mérlegés eredményadatokra alapozott, összetett mutatókra épül, a pénzügyi vállalkozások további tetszőleges alszegmentációjára is lehetőség nyílik, például engedélyezett tevékenységi kör szerinti kockázatok felmérése, romló, folyamatosan lefelé migráló minősítésű vállalkozások leválogatása és a folyamataikban rejlő kockázatok mélyebb elemzése stb. 


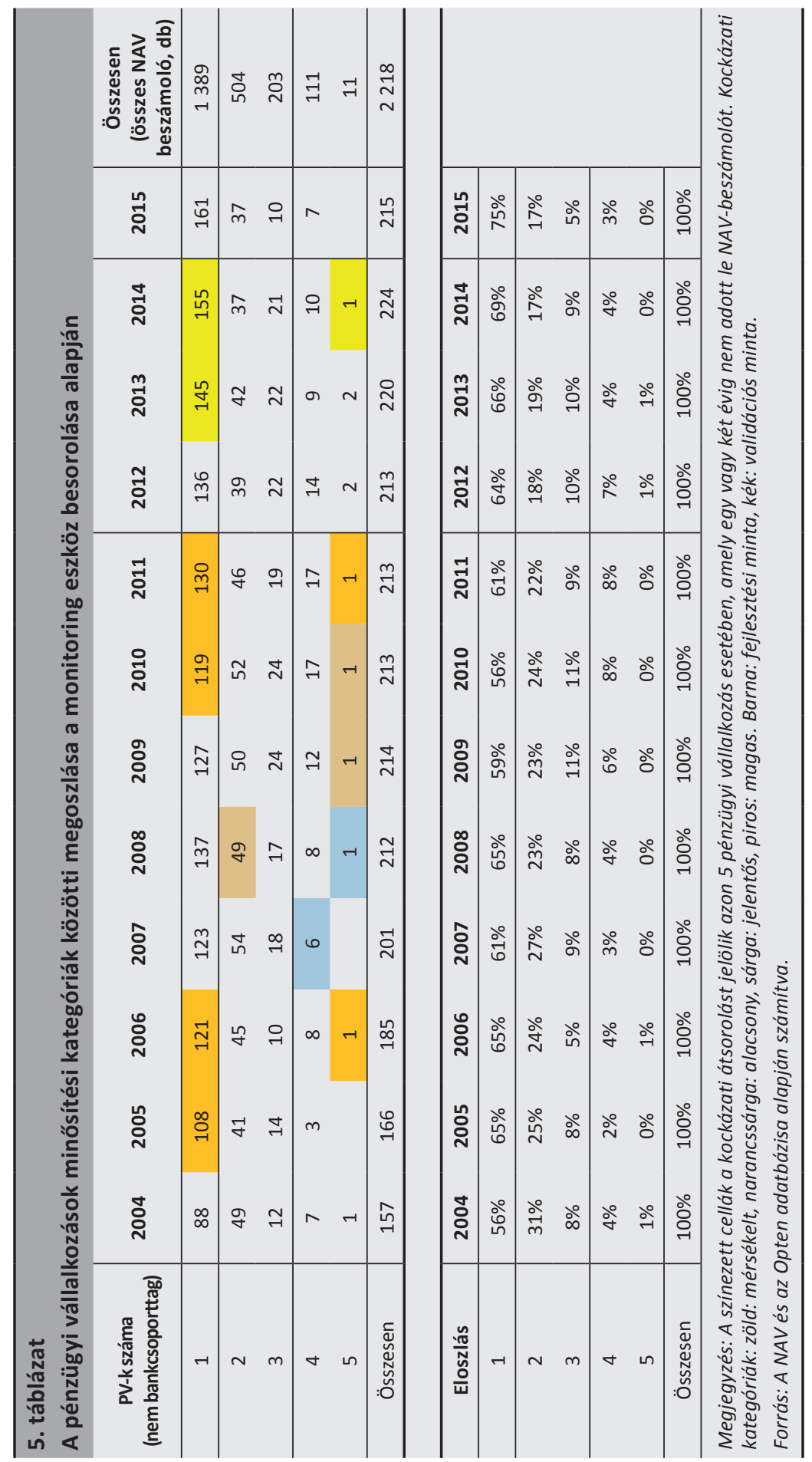


A fenti táblázat kiegészítéseként a 2. melléklet mutatja be az 5. táblázatban megjelenített, adott évi minősítési eloszlásokkal kisúlyozott, 1 évre előre jelzett negatív esemény rátát, az adott évi NAV-beszámoló fordulónapjától számított 1 éven belüli ténylegesen bekövetkezett negatív esemény rátával összevetve. A 2. melléklet alapján nem csupán a monitoring eszköz ciklusfüggő jellege látszik ismételten, hanem az is, hogy további kalibráció a negatív esemény valószínűség tekintetében nem szükséges, hiszen mind szintjében, mind dinamikájában megfelelően követi le a ténylegesen megvalósuló negatív eseményeket, azok arányát a NAV-beszámolót leadó nem bankcsoporttag pénzügyi vállalkozások esetében. Mindazonáltal, tekintettel a negatív események alacsony arányára, a kockázati monitoringot összevonva 3 kategóriára, például logikusan az 1., a 2-3. és a 4-5. kategóriákból képezve 3 jelzőlámpa jellegű kategóriát érdemes használni, mert ebben az esetben már 2 éves előre tekintő időtávon egy év kivételével minden évben monoton kockázati sorba rendezést kapunk (ezt vizuálisan kiemelve szemlélteti a 4. és az 5. táblázat).

\section{Bayes-i paraméterbecslés}

A frekventista paraméterbecslés alacsony eseményszám (a ritkábbik kategória, jelen publikációban a jogi negatív esemény) esetében ismert módon bizonytalan azért, mert nehezen számszerűsíthető. A vonatkozó szakirodalom alapján többféle hüvelykujjszabály ismeretes. Peduzzi és szerzőtársai (1996) minimálisan $t_{n}=\frac{10 k}{p}$ mintaméretet tartanak szükségesnek a paraméterek megfelelő becsléséhez, ahol $n$ a mintaméret, $k$ a magyarázó változók száma, $p$ pedig az eseményarány. Esetünkben p 1,28 százalék a fejlesztési mintán (2004-2011. évi NAV-beszámoló minta), 10k pedig 50, tehát $n=3890$ elemű mintára lenne szükség a szerzők véleménye szerint a paraméterek megbízható becsléséhez - amelynek a fejlesztési minta 1556 elemü mintája csak mintegy 40 százaléka. Ugyanakkor egy újabb publikációban Vittinghoff és McCulloch (2007) széles körű szimulációs vizsgálatok alapján a fenti szabályt túlzottan szigorúnak tartják, és elsődlegesen a másodfajú hiba túl gyakori előfordulását jelölték meg problémaként, még abban az esetben is, ha a fentebbiek szerint $k<5$. Mindezek, valamint a modell már ismertetett időkizárt validációs mintán nyújtott kiváló teljesítménye miatt nem jelentős a modellkockázat.

Összegezve, az ehelyütt is ismertetett nemzetközi szakirodalom is rávilágít a frekventista paraméterbecslés problémáira, amelyek között említhetjük a szignifikanciával kapcsolatos (első- és másodfajú hiba), a paraméterek pontbecslés jellegéből adódó, azok prediktív eloszlásának hiányából adódó bizonytalanság miatti, valamint a kapcsolódó egyéb filozófiai kérdéseket - vajon definiálhatjuk-e a valószínűséget gyakoriságként olyan esetekben, amikor elviekben sem állíthatunk elő reprodukálással mintákat (Jaynes - Bretthorst 2003). Ezen problémakör tárgyalása messze túlmutat jelen publikáció keretein, ugyanakkor, minthogy a közgazdasági idősorok, adatbázisok - így kiemelten a jelen publikációban használt adatkör is - egyediek, 
viszonylag alacsony mintelem- és eseményszámmal, érdemes az ilyen jellegű esetekben gyakran használt bayes-i becslőeljárást is alkalmazni. Ezen eljárás a szignifikanciaszint helyett hihetőségi intervallumokon keresztül ragadja meg a becsült paraméterek értékeiben rejlő bizonytalanságot, prediktív eloszlást rendel a paraméterekhez és ezen keresztül a kimeneti változó előre jelzett értékeihez, valamint a már rendelkezésre álló tudás becslésbe történő becsatornázásán keresztül pontosabb reprezentációt ad a minta és a szakértői tudás alapján aktuálisan meghatározható valószínúségekről (a modell valószínúsége alternatívákkal szemben, paraméterek prediktív eloszlása stb.).

Ismert módon, a bayes-i paraméterbecslés a paraméter előzetes ismereteink alapján adott eloszlása $(P(\theta))$ és az adatok, valamint az adott módon specifikált modell alapján $(P($ adatok $\mid \theta))$ adja meg a paraméterek utólagos, ún. posterior eloszlását:

$$
P(\theta \mid \text { adatok })=\frac{P(\text { adatok } \mid \theta) p(\theta)}{\sum_{\theta^{\prime}}^{\Theta} P\left(\text { adatok } \mid \theta^{\prime}\right) P\left(\theta^{\prime}\right)},
$$

azaz a bayes-i eljárás szerint a világról alkotott előzetes ismereteinket frissítjük az újonnan érkező evidencia, információ alapján (MacKay 2003). Jelen esetben a fejlesztési minta előtti ismereteinkkel kapcsolatban azt feltételezzük, hogy lényegében nem informatívak - a logisztikus regresszió tengelymetszete és súly paramétereire is a paraméterértékek széles skálájához még érdemi valószínűséget rendelő normális eloszlást határoztuk meg, feltételezve a többdimenziós függetlenséget a prior eloszlás meghatározása során:

$$
P(\theta) \sim N(0,10)
$$

Az (1), (2) és (3) alapján, a (2) egyenletből a normalizáló konstanst elhagyva megkapjuk a Markov-lánc Monte-Carlo-módszerrel (MacKay 2003) a (3) szerinti prior paramétereloszlást, valamint a fejlesztési minta alapján szimulálható posterior eloszlást, logisztikus regresszió és a fentebb már bemutatott változók alkalmazásával:

$$
P(\theta \mid \text { fejlesztési adatok }) \propto L(\text { fejlesztési adatok } \mid \theta) N(0,10) .
$$

A szimuláció során a prior eloszlás egy véletlen húzással meghatározott pontjából indítva 25000 elemet húztunk a posterior eloszlásból, az első 2500 elemet pedig eldobtuk a posterior statisztikák számítása során (a szakirodalomban is ismert „burnin"). Utolsó lépésként pedig, a paraméterek és ezen keresztül a modell stabilitásának felmérése érdekében, a validációs mintán, feltételezve a (4) posterior paramétereloszlás több-dimenziós normalitását (azaz, a posterior eloszlás Laplace-approximációja során többdimenziós normális eloszlást felhasználva), elvégeztük a becslést a validációs mintán is, az alábbiak szerint: 


$$
P(\theta \mid \text { validációs adatok }) \propto L(\text { validációs adatok } \mid \theta) P(\theta \mid \text { fejl.adatok }) .
$$

Azaz (5) szerint a korábbi információkat frissítettük az újonnan beérkező információs bázis alapján, összhangban a bayes-i módszertannal, valamint a kapcsolódó legjobb gyakorlattal. Jelen eljárás számos gyakorlati alkalmazás során bizonyította életképességét, köztük olyan, igen ritka események vizsgálata során, mint például a német tengeralattjárók atlanti-óceáni, hatalmas térségben történő detektálása (Koopman 1946), melynek keretében az Egyesült Államok hadserege 200 x 50 mérföldes cellákon belül kereste a néhány tíz méter hosszúságú tengeralattjárókat. Ezen keresés hatékonyságán javított jelentősen a jelen publikációban is használt bayes-i módszertan, illetőleg az információk annak keretében történő hatékonyabb felhasználása.

A bayes-i becslés eredményeit, valamint annak a 2. táblázatban bemutatott frekventista paraméterbecsléssel történő összevetését mutatja be a 6. táblázat.

\begin{tabular}{|c|c|c|c|c|c|c|}
\hline \multicolumn{7}{|c|}{$\begin{array}{l}\text { 6. táblázat } \\
\text { A pénzügyi vállalkozások fejlesztési (2004-2011. évi NAV-beszámoló) és validációs } \\
\text { (2012-2014. évi NAV-beszámoló) mintáján becsült paraméterek frekventista és } \\
\text { bayes-i módszerrel }\end{array}$} \\
\hline \multirow[b]{2}{*}{ Változó } & \multicolumn{2}{|c|}{$\begin{array}{l}\text { Maximum likelihood } \\
\text { fejlesztés }\end{array}$} & \multicolumn{2}{|c|}{$\begin{array}{c}\text { Bayes-i becslés } \\
\text { fejlesztés }\end{array}$} & \multicolumn{2}{|c|}{$\begin{array}{l}\text { Bayes-i becslés } \\
\text { validáció }\end{array}$} \\
\hline & $\begin{array}{c}\text { Becsült } \\
\text { paraméter }\end{array}$ & $\begin{array}{l}\text { Standard } \\
\text { hiba }\end{array}$ & $\begin{array}{c}\text { Becsült } \\
\text { paraméter }\end{array}$ & $\begin{array}{l}\text { Standard } \\
\text { hiba }\end{array}$ & $\begin{array}{l}\text { Becsült } \\
\text { paraméter }\end{array}$ & $\begin{array}{l}\text { Standard } \\
\text { hiba }\end{array}$ \\
\hline Tengelymetszet & $-5,675$ & 0,449 & $-5,779$ & 0,476 & $-5,764$ & 0,571 \\
\hline ROA & $-0,327$ & 1,061 & $-0,659$ & 0,922 & $-0,649$ & 0,888 \\
\hline $\begin{array}{l}\text { Hosszú távú } \\
\text { megtérülés }\end{array}$ & $-0,415$ & 0,102 & $-0,396$ & 0,11 & $-0,393$ & 0,114 \\
\hline $\begin{array}{l}\text { Rövid távú } \\
\text { likviditás }\end{array}$ & 0,229 & 0,067 & 0,222 & 0,07 & 0,221 & 0,085 \\
\hline $\begin{array}{l}\text { Egy FTE-re jutó } \\
\text { átlagos üzemi } \\
\text { eredmény }\end{array}$ & $-0,059$ & 0,030 & $-0,064$ & 0,034 & $-0,062$ & 0,036 \\
\hline $\begin{array}{l}\text { Nettó } \\
\text { amortizációs } \\
\text { ráta }\end{array}$ & $-0,396$ & 0,128 & 0,386 & 0,139 & $-0,386$ & 0,143 \\
\hline
\end{tabular}

Forrás: A NAV és az Opten adatbázisa alapján számítva

A 6. táblázat alapján, a maximum likelihood, a nem-informatív prior alkalmazásával a fejlesztési mintán végrehajtott bayes-i becslés, valamint a validációs mintán informatív - a korábbi információkat becsatornázó - priorral végrehajtott bayes-i becslés közel hasonló eredményeket ad. Az egyetlen kivétel az eszközarányos megtérülés mutató (ROA), amelynek becsült értéke jelentősen eltér a két módszertan alapján. Ennek magyarázata, hogy egyik módszertan szerint sem erős változó, ame- 
lyet egyébként a 2. táblázatban szereplő sztenderdizált regressziós súly értéke (4,8 százalék) is visszaigazol.

Mindazonáltal, mind a frekventista becslés során alkalmazott időkizárt keresztvalidáció, mind a bayes-i módszertan szerinti paraméterbecslés alapján stabil, erős prediktív erővel rendelkező minősítő rendszer állítható fel. Az egyetlen különbség a kétféle megközelítésben az egyébként is alacsony súllyal szereplő, de szakértői megfontolásokból a modellben tartott eszközarányos megtérülés súlyozásában van, ami azonban értelemszerűen nem módosít a modell előrejelző erejének megfelelőségén.

\subsection{Jelzőlámpa-rendszerú monitoring a kockázati szegmentáció alapján}

Amint arra a 2.2. fejezet Frekventista paraméterbecslés alrészében utaltunk, a kockázati szegmentáció egyértelmúbbé tehető az 1., 2-3., valamint a 4-5. kategóriákból képzett, három osztatú jelzőlámparendszer alkalmazásával. Ezen a módon ugyanis a 2 éves negatív eseményarány csaknem minden évben monoton lesz, és egyértelmü, könnyeben interpretálható eredményeket ad. Az 1., „zöld” kategória a jó minőségú, finanszírozható, alacsony kockázatú pénzügyi vállalkozásokat tartalmazza, a 2., „sárga” kategória tartalmazza a potenciálisan magas kockázatúvá váló pénzügyi vállalkozásokat, míg a 3., „Vörös" kategóriába a kifejezetten problémás, magas kockázatú pénzügyi vállalkozások kerülnek (7. táblázat). A jelzőlámparendszer alapján egyszerübb, nyomon követhetőbb és megalapozottabb lehet a finanszírozói döntés - például a "sárga” és „vörös" minősítésű pénzügyi vállalkozások finanszírozásának fokozatos leépítése, illetve az ezen kategóriába tartozó pénzügyi vállalkozások fokozott monitoringja.

7. táblázat
Jelzólámparendszer a nem bankcsoporti pénzügyi vállalkozások kockázati
monitoringjára
\begin{tabular}{c|c|c|c|c|c|c|c|c|c|c|c|c} 
& $\mathbf{2 0 0 4}$ & $\mathbf{2 0 0 5}$ & $\mathbf{2 0 0 6}$ & $\mathbf{2 0 0 7}$ & $\mathbf{2 0 0 8}$ & $\mathbf{2 0 0 9}$ & $\mathbf{2 0 1 0}$ & $\mathbf{2 0 1 1}$ & $\mathbf{2 0 1 2}$ & $\mathbf{2 0 1 3}$ & $\mathbf{2 0 1 4}$ & $\mathbf{2 0 1 5}$ \\
\hline 1 & $0,0 \%$ & $0,9 \%$ & $0,8 \%$ & $0,0 \%$ & $0,0 \%$ & $0,8 \%$ & $3,4 \%$ & $1,5 \%$ & $0,0 \%$ & $0,7 \%$ & $0,6 \%$ & $0,0 \%$ \\
\hline 2 & $1,6 \%$ & $1,8 \%$ & $1,8 \%$ & $2,8 \%$ & $1,5 \%$ & $1,4 \%$ & $3,9 \%$ & $3,1 \%$ & $3,3 \%$ & $3,1 \%$ & $6,9 \%$ & $0,0 \%$ \\
\hline 3 & $12,5 \%$ & $0,0 \%$ & $33,3 \%$ & $33,3 \%$ & $11,1 \%$ & $23,1 \%$ & $22,2 \%$ & $27,8 \%$ & $31,2 \%$ & $27,3 \%$ & $18,2 \%$ & $0,0 \%$ \\
\hline & $1,27 \%$ & $1,20 \%$ & $2,70 \%$ & $1,99 \%$ & $0,94 \%$ & $2,34 \%$ & $5,16 \%$ & $4,23 \%$ & $3,29 \%$ & $2,73 \%$ & $3,13 \%$ & $0,00 \%$ \\
\hline
\end{tabular}

Forrás: A NAV és az Opten adatbázisa alapján számítva

\section{Konklúzió}

Tekintettel arra, hogy a pénzügyi vállalkozások ügyfélpénzt nem kezelnek, kockázat elsősorban a refinanszírozó vagy tulajdonos hitelintézetek oldaláról valósul meg, emellett ezen intézmények esetében a fogyasztóvédelmi kockázatok emelhetők még ki. 
A fejlesztett eszköz jelentősége abban áll, hogy a nem bankcsoporttag pénzügyi vállalkozások esetén hiánypótló jelleggel mutat be egy hazai bankok számára is elérhető mérleg- és eredményadatokon alapuló monitoring-modellt, amely hatékony addicionális eszköz lehet a refinanszírozási kockázatok mérésére. Mindezen információk mind befektetői, mind kockázatértékelői szempontokból hasznosak, értékesek lehetnek.

Kiemelendő továbbá, hogy az eszköz korai figyelmeztető jelzőrendszerként is használható adott esetben. Annak ellenére, hogy a modell alapvetően időpillanatot jellemző („point-in-time”) változókat használ, a 4. táblázat alapján összevonva 3 jelzőlámpa-rendszerú kategóriára (például az 1., a 2-3. és a 4-5. kategóriákból képezve 3 kategóriát), akár kétéves időtávon is megfelelően mutatja az adott pénzügyi vállalkozás relatív kockázatosságát, ez pedig elégséges idő a megfelelő kockázatkezelési döntések meghozatalára, vagy a kockázati monitoring minősítésromlása esetén azok felülvizsgálatára és a felülvizsgálat érvényre juttatására.

Végezetül fejlesztési irányként jelölhetjük meg a monitoring eszköz továbbfejlesztését addicionális információk becsatornázásával, így például az adott pénzügyi vállalkozásra vonatkozó negatív információk felhasználását. Ezek között említhetjük bíróságon a vállalkozás ellen indított eljárást, a bankszámla-sorbanállást, valamint a pénzügyi vállalkozás menedzsmentjében bekövetkező, adott esetben negatív jellegú változásokat. Egy további fejlesztési irány lehet mikroszintű adatok becsatornázása a pénzügyi vállalkozások kockázatmérésébe. Ez utóbbi az adott pénzügyi vállalkozás által finanszírozott lakossági és - elsődlegesen a vállalati profilú pénzügyi vállalkozások esetén - vállalati ügyletek és ügyfelek minősítésén alapulna, azaz egy további mérlegelemzési szempontot adna a pénzügyi vállalkozások minősítéséhez a már jelenleg is felhasznált mérlegmutatók mellé.

Előzetes felmérések, számítások alapján továbbá a modell a bankcsoporttag pénzügyi vállalkozások relatív kockázatosságának, üzletági hatékonyságának mérését is támogathatja (tekintettel arra, hogy a bankcsoportok jellemzően egy-egy tevékenységre, üzleti folyamatra szerveznek pénzügyi vállalkozást, például lízing, faktoring stb.), így ennek részletesebb elemzését is érdemesnek tartjuk.

\section{Felhasznált irodalom}

Agresti, A. (1990): Categorical Data Analysis, 3rd Edition. John Wiley \& Sons, New York.

Banai Ádám - Hosszú Zsuzsanna - Körmendi Gyöngyi - Sóvágó Sándor - Szegedi Róbert (2013): Stressztesztek a Magyar Nemzeti Bank gyakorlatában (Stress tests in the Magyar Nemzeti Bank's practice). MNB Occasional Papers 109. 
Bauer Péter - Endrész Marianna (2016): Modelling Bankruptcy Using Hungarian Firm-Level Data. MNB Working Papers 122.

Broos, M. - Carlier, K. - Kakes, J. - Klaaijsen, E. (2012): Shadow Banking: An Exploratory Study for the Netherlands. DNB Occasional Studies, https://www.dnb.nl/en/binaries/ DNB_OS_10-05_uk_tcm47-281218.pdf. Letöltés ideje: 2017. január 2.

Hastie, T. - Tishbirani, R. - Friedman, J. (2008): The Elements of Statistical Learning, 2nd Edition. Springer Verlag, Berlin.

Hajdu Ottó - Virág Miklós (1996): Pénzügyi mutatószámokon alapuló csődmodell-számítások (Bankruptcy model calculations based on financial indicators). Bankszemle, 15(5): 42-53.

Hajdu Ottó - Virág Miklós (2001): A Hungarian Model for Predicting Financial Bankruptcy. Society and Economy in Central and Eastern Europe, 23(1-2): 28-46.

Hill, N. - Auquier, R. (2014): Proposed Bank Rating Methodology. Moody's Report Number: 171718. https://www.moodys.com/microsites/gbrm2014/RFC.pdf. Letöltés ideje: 2017. január 2.

Hong, Ch. S. - Ryu, H.S. (2006): Information Theoretic Standardized Logistic Regression Coefficients with Various Coefficients of Determination. The Korean Communications in Statistics, 13(1): 49-60. https://doi.org/10.5351/CKSS.2006.13.1.049

Jaynes, E. - Bretthorst, L. (2003): Probability Theory - the Logic of Science. Cambridge University Press, Cambridge

Joopia, H. (2016): Optimal Binning for Scoring Modelling. http://www.scoringmodeling.com/. Letöltés ideje: 2017. január 2.

Koopman, B. (1946): Search and Screening. OEG Report No.56.

Kristóf Tamás (2008): A csődelörejelzés és a nem fizetési valószínüség számításának módszertani kérdéseiröl. Közgazdasági Szemle, 55 (Május): 441-461.

Liao, J. - McGee, D. (2003): Adjusted Coefficients of Determination for Logistic Regression. The American Statistician, 57(3): 161-165. https://doi.org/10.1198/0003130031964

MacKay, D. (2003): Information Theory, Inference and Learning Algorithms. Cambridge University Press, Cambridge.

MNB (2016a): A Magyar Nemzeti Bank 11/2016 (XII.1.) számú ajánlása az árnyékbanki tevékenységet végző szervezetekkel szembeni kitettségek korlátozásáról. MNB 11/2016. https://www.mnb.hu/letoltes/11-2016-shadow-banking.pdf. Letöltés ideje: 2017. január 2. 
MNB (2016b): Bankszektoron kívüli pénzügyi piacok kockázati jelentése. MNB 2016, pp. 51-53. http://www.mnb.hu/letoltes/publikalando-jelentes-v4-digitalis.pdf. Letöltés ideje: 2017. január 3.

MNB (2017): Biztosítási, pénztári és tőkepiaci kockázati jelentés, 2017. június. MNB. pp. 58-65. http://www.mnb.hu/letoltes/kocka-zati-jelente-s-2017-digita-lis.pdf. Letöltés ideje: 2018. október 18.

MNB (2018): Biztositási, pénztári és tőkepiaci kockázati jelentés, 2018. MNB 2018., pp. 61-67. http://www.mnb.hu/letoltes/kockazati-jelentes-2018-0613-vegleges.PDF. Letöltés ideje: 2018. október 18.

Packer, F. - Tarashev, N. (2011): Rating methodologies for banks. BIS Quarterly review, június. http://www.bis.org/publ/qtrpdf/r_qt1106f.pdf. Letöltés ideje: 2017. január 2.

Peduzzi, P. - Concato, J. - Kemper, E. - Holford, T. R. - Feinstein, A. R. (1996): A simulation study of the number of events per variable in logistic regression analysis. Journal of Clinical Epidemiology, 49(12): 1373-1379. https://doi.org/10.1016/S0895-4356(96)00236-3

Tripolitakis, G. - Angelopoulos, G. - Wu, Y. - Baldassari, G. (2015): CreditModel Financial Institutions. Standard and Poor's Capital IQ. http://marketintelligence.spglobal.com/ documents/our-thinking/research/creditmodel-financial-institutions-a-state-of-the-artscoring-model-for-banks-and-insurance-companies.pdf. Letölés ideje: 2017. január 2.

Vittinghoff, E. - McCulloch, C. E. (2007): Relaxing the rule of ten events per variable in logistic and Cox regression. American Journal of Epidemiology, 165(6): 710-718. https:// doi.org/10.1093/aje/kwk052 


\section{Melléklet}

\section{1. melléklet: A felhasznált változók keresztkorrelációs vizsgálata}

\begin{tabular}{l|c|c|c|c|c}
\hline \multicolumn{1}{l}{ Metrika: Spearman rho } & RoA & $\begin{array}{c}\text { Hosszú távú } \\
\text { megtérülés }\end{array}$ & $\begin{array}{c}\text { Rövid távú } \\
\text { likviditás }\end{array}$ & $\begin{array}{c}\text { Egy FTE-re jutó } \\
\text { adózás előtti } \\
\text { eredmény }\end{array}$ & $\begin{array}{c}\text { Nettó } \\
\text { amortizációs } \\
\text { rejlesztési } \\
\text { minta }\end{array}$ \\
\hline ROA & 0,389 & $-0,048$ & 0,357 & 0,057 \\
\hline $\begin{array}{l}\text { Hosszú távú } \\
\text { megtérülés }\end{array}$ & 0,389 & $-0,116$ & $-0,116$ & 0,182 & 0,022 \\
\hline $\begin{array}{l}\text { Rövid távú } \\
\text { likviditás }\end{array}$ & $-0,048$ & 0,182 & $-0,029$ & $-0,029$ & $-0,022$ \\
\hline $\begin{array}{l}\text { Egy FTE-re jutó } \\
\text { adózás elótti } \\
\text { eredmény }\end{array}$ & 0,357 & 0,022 & $-0,022$ & $-0,011$ & $-0,011$ \\
\hline $\begin{array}{l}\text { Nettó } \\
\text { amortizációs } \\
\text { ráta }\end{array}$ & 0,057 & & & & \\
\hline
\end{tabular}

\begin{tabular}{l|c|c|c|c|c}
\hline $\begin{array}{l}\text { Validációs } \\
\text { minta }\end{array}$ & ROA & $\begin{array}{c}\text { Hosszú távú } \\
\text { megtérülés }\end{array}$ & $\begin{array}{c}\text { Rövid távú } \\
\text { likviditás }\end{array}$ & $\begin{array}{c}\text { Egy FTE-re jutó } \\
\text { adózás előtti } \\
\text { eredmény }\end{array}$ & $\begin{array}{c}\text { Nettó } \\
\text { amortizációs } \\
\text { ráta }\end{array}$ \\
\hline ROA & 0,245 & $-0,015$ & 0,461 & 0,061 \\
\hline $\begin{array}{l}\text { Hosszú távú } \\
\text { megtérülés }\end{array}$ & 0,245 & $-0,070$ & 0,120 & 0,172 \\
\hline $\begin{array}{l}\text { Rövid távú } \\
\text { likviditás }\end{array}$ & $-0,015$ & $-0,070$ & & $-0,029$ & $-0,041$ \\
\hline $\begin{array}{l}\text { Egy FTE-re jutó } \\
\text { adózás elótti } \\
\text { eredmény }\end{array}$ & 0,461 & 0,120 & $-0,029$ & & $-0,048$ \\
\hline $\begin{array}{l}\text { Nettó } \\
\text { amortizációs } \\
\text { ráta }\end{array}$ & 0,061 & 0,172 & $-0,041$ & $-0,048$ & \\
\hline
\end{tabular}

Forrás: A NAV adatbázisa alapján számítva 


\section{2. melléklet: A ténylegesen megvalósult és az előre jelzett negatív esemény ráta}

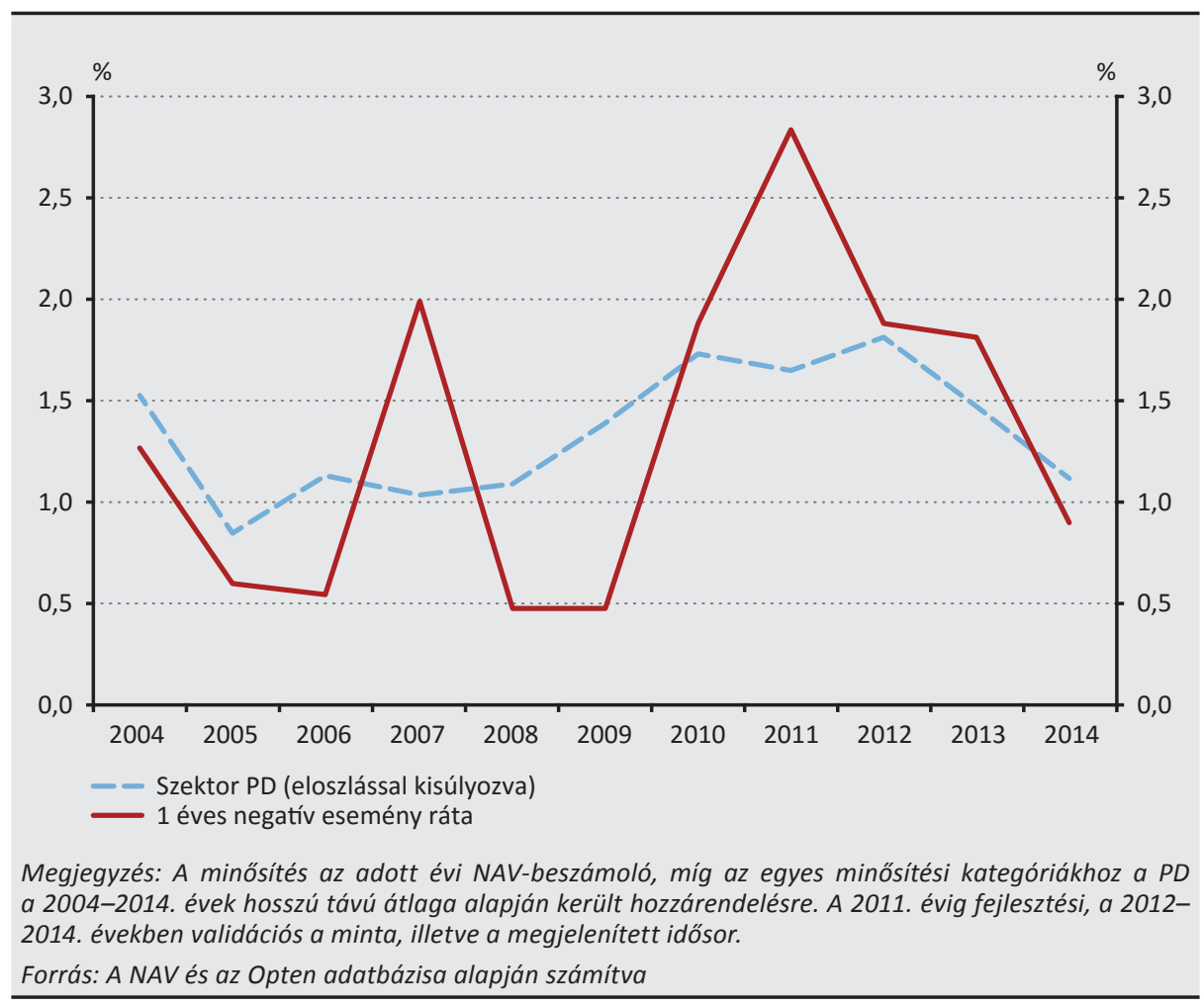




\section{3. melléklet: A bayes-i becslés során a fejlesztési mintán alkalmazott prior és a becslés alapján kapott posterior eloszlások}

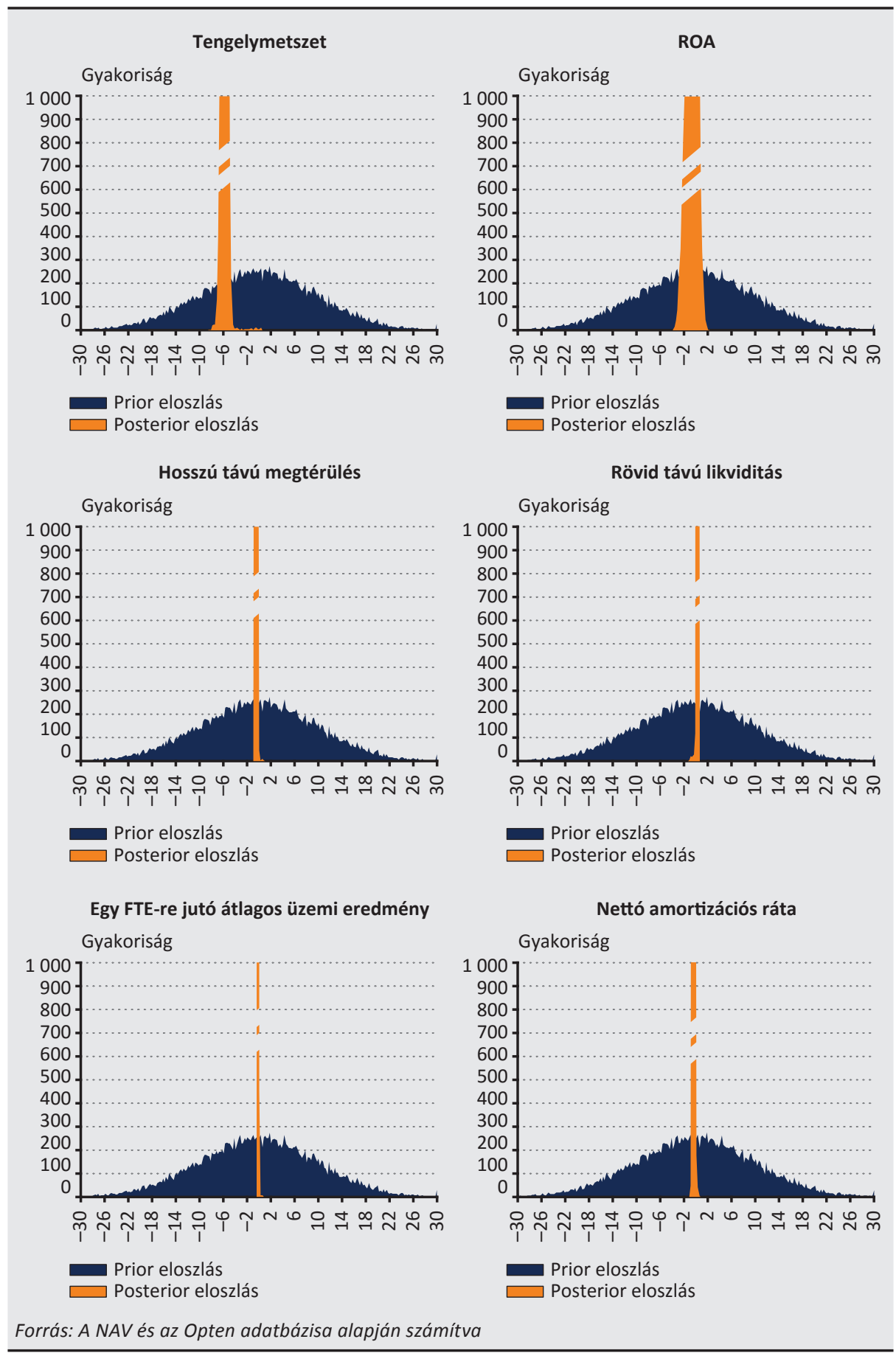

